\title{
IDENTIFIKASI KEBUTUHAN AIR BERSIH DAN TIMBULAN AIR LIMBAH TEMPAT PELELANGAN IKAN DESA KARANGSONG, KECAMATAN INDRAMAYU, KABUPATEN INDRAMAYU
}

\author{
Yonik Meilawati Yustiani", Lili Mulyatna, Suwirkas \\ Program Studi Teknik Lingkungan, Universitas Pasundan
}

\begin{abstract}
Abstrak
Sampai saat ini di Indramayu belum memiliki Tempat Pelelangan Ikan (TPI) yang menerapkan sistem sanitasi yang higienis. Penerapan sistem fasilitas sanitasi yang higienis mutlak diperlukan untuk memberikan keamanan dan kenyamanan bagi pengguna dan lingkungan sekitarnya.Tempat Pelelangan Ikan Karangsong di Kabupaten Indramayu menempati lahan seluas $4000 \mathrm{~m}^{2}$ dilengkapi dengan beberapa fasilitas pendukung, dilengkapi dengan dermaga yang berfungsi sebagai tempat bersandarnya kapal atau perahu ketika membongkar muatan. Tujuan penelitian in adalah untuk mengidentifikasi kebutuhan air bersih dan timbulan air buangan di Tempat Pelelangan Ikan Karangsong Kabupaten Indramayu. Identifikasi ini dapat dimanfaatkan sebagai dasar penentuan konsep penyediaan prasarana agar dapat berjalan secara efisien dan efektif sesuai dengan tingkat pelayanan yang direncanakan. Metode yang digunakan dalam penelitian ini yaitu metode deskriptif, mengamati dan mengambil data kondisi eksisting serta menentukan alternatif penyediaan fasilitas sanitasi untuk TPI higienis sesuai dengan literatur yang tersedia. Perhitungan menunjukkan bahwa kebutuhan air minum adalah 0,025 liter/detik, dengan fluktuasi 0,04375 liter/detik. Secara total, kebutuhan air bersih untuk TPI ini adalah 1,862 liter/detik. Jumlah air buangan yang ditimbulkan adalah 1,494 liter/detik. Hasil identifikasi karakteristik air buangan menunjukkan bahwa nilai BOD mencapai nilai $836 \mathrm{mg} / \mathrm{L}$, COD sebesar $128 \mathrm{mg} / \mathrm{L}$ dan nitrat sebesar $150 \mathrm{mg} / \mathrm{L}$. Nilai konsentrasi yang ditunjukkan dari karakteristik limbah TPI menunjukkan perlunya disediakan instalasi pengolahan air limbah dengan efisiensi yang tinggi. Unit utama dalam pengolahan air limbah TPI ini adalah septic tank termodifikasi.
\end{abstract}

Kata kunci: kebutuhan air bersih, timbulan air limbah, TPI higienis

\section{Pendahuluan}

Pembangunan Tempat Pelelangan Ikan (TPI) merupakan sarana terencana yang disediakan oleh pemerintah daerah sebagai wadah untuk menampung dan menjual hasil tangkapan laut, termasuk jasa bongkar muat dan pasar ikan. Kegiatan seperti ini mengundang banyak orang, baik nelayan sebagai produsen maupun pedagang sebagai konsumen. Dalam melakukan transaksi lelang ikan dan hasil tangkapan laut lainnya, air bekas cucian dan sisa-sisa potongan

\footnotetext{
${ }^{*}$ Penulis Korespondensi:

E-mail: yonik@unpas.ac.id
}

Diterima pertama kali: 3 Mei 2018

Direvisi : 16 Juli 2018

Disetujui untuk publikasi: 25 Agustus 2018 ikan serta timbulan sampah yang lain dapat menyebabkan Tempat Pelelangan Ikan menjadi kotor dan bau amis. Kondisi seperti ini yang menyebabkan daerah di sekitar Tempat Pelelangan Ikan menjadi kumuh dan tercemar. Untuk mengubah kondisi ini diperlukan penataan kembali tempat-tempat pelelangan ikan termasuk penerapan sistem fasilitas sanitasi higienis. Sampai saat ini di Indramayu belum ada Tempat Pelelangan Ikan yang menerapkan sistem sanitasi yang higienis. Penerapan sistem fasilitas sanitasi yang higienis mutlak diperlukan untuk memberikan keamanan dan kenyamanan bagi pengguna dan lingkungan sekitarnya. Oleh sebab itu dalam penelitian ini dilakukan perencanaan fasilitas sanitasi untuk Tempat 
Pelelangan Ikan Higienis yang meliputi air minum, air limbah, drainase dan sampah.

Tempat Pelelangan Ikan Karangsong di Kabupaten Indramayu menempati lahan seluas $4000 \mathrm{~m}^{2}$ dilengkapi dengan beberapa fasilitas pendukung seperti gedung Tempat Pelelangan Ikan, kantor pengelola Tempat Pelelangan Ikan, kantor Koperasi Perikanan Laut, depot dan tempat penggilingan es, toko suku cadang perahu motor, stasiun pengisian bahan bakar motor, musola, balai pertemuan, WC umum dan pos security serta area parkir kendaraan dan area bongkar muat barang. Selain fasilitas tersebut diatas Tempat Pelelangan Ikan Karangsong juga dilengkapi dermaga yang berfungsi sebagai tempat bersandarnya kapal atau perahu ketika membongkar muatan. Tempat Pelelangan Ikan Karangsong terletak kira-kira 1000 m dari pantai ke arah daratan melalui aliran sungai yang menghubungkan antara laut dengan dermaga dengan demikian Tempat Pelelangan Ikan ini aman dari gangguan gelombang atau air laut pasang.

Tujuan penelitian in adalah untuk mengidentifikasi kebutuhan air bersih dan timbulan air limbah di Tempat Pelelangan Ikan Karangsong Kabupaten Indramayu sehingga dapat digunakan oleh pengelola dalam penyediaan prasarana TPI higinsi secara efisien dan efektif sesuai dengan tingkat pelayanan yang direncanakan.

\section{Metodologi}

\section{Metode yang Digunakan}

Metode yang digunakan dalam penelitian ini yaitu metode deskriptif. Metode deskriptif adalah metode yang mempelajari masalahmasalah dalam masyrakat, tatacara dalam masyrakat dalam situasi tertentu termasuk tentang hubungan kegiatan-kegiatan,sikap-sikap, pandangan-pandangan, serta proses-proses yang sedang berlangsung dan pengaruh-pengaruh dari suatu penomena. Dalam metode deskriptif peneliti bisa saja membandingkan penomenapenomena tertentu sehingga merupakan studi komparatif. Adakalanya dilakukan klasifikasi serta penelitian terhadap penomena-penomena dengan menetapkan suatu standar atau norma tertentu. Dengan metode deskriptif ini juga diselidiki kedudukan (status) fenomena atau faktor-faktor dan melihat hubungan antara satu faktor dengan faktor yang lain. Karenanya metode deskriptif juga dinamakan studi status (status study).

Dalam metode deskriptif dapat diteliti masalah normatif bersama-sama dengan masalah status dan sekaligus membuat perbandinganperbandingan antara penomena. Perspektif waktu yang dijangkau dalam penelitian deskriptif adalah waktu sekarang atau sekurangkurangnya jangka waktu yang masih terajangkau dalam ingatan responden.

\section{Teknik Pengumpulan Data}

Sesuai dengan metode yang dipilih dalam penelitian ini, maka teknik pengumpulan data yang digunakan adalah :

\section{Studi Literatur}

Tahapan ini dilalukan guna memahami prinsip dasar dari sistem fasilitas sanitasi tempat pelelangan ikan higienis secara baik dan lengkap, baik itu mengenai air bersih, air limbah, air hujan dan persmpahan dengan segala ateori dan perhitungan yang digunakan dalam materi ini. Selain itu juga diharapkan dapat menggali teori-teori dan ilmu pengetahuan yang berkembang dalam bidang ini sehingga dapat memperoleh orientasi yang lebih luas dalam memahami teori-teori dan ilmu pengetahuan itu sendiri.

Studi literatur, selain mencari sumber data sekunder juga diperlukan untuk mengetahui 
sejauh mana dalam bidang sanitasi lingkungan ilmu pengetahuan telah berkembang.

\section{Survey Pendahuluan}

Pada tahapan ini adalah pengambilan data dengan cara langsung mendatangi lokasi tempat pelelangan ikan. Hal ini perlu dilakukan untuk memperoleh gambaran kondisi dan kegiatan tempat pelelangan ikan sehingga dapat diketahui dan dipahami fasilitas apa saja yang ada dan harus ada karena memang diperlukan. Pengamatan tergolong sebagai pengumpulan data apabila pengamatan tersebut mempunyai kriteria sebagai berikut :

1. Pengamatan digunakan untuk penelitian dan telah direncanakan secara sistematik.

2. Pengamatan harus berkaitan dengan tujuan penelitian yang telah direncanakan.

3. Pengamatan tersebut dicatat secara sistematis dan dihubungkan dengan proposisi umum dan bukan dipaparkan sebagai suatu set yang menarik perhatian saja

4. Pengamatan dapat dicek dan dikontrol atas validitas dan reabilitasnya.

Cara memperoleh data dengan pengamatan langsung mempunyai beberapa keuntungan diantaranya :

1. Terdapat kemungkinan untuk mencatat halhal, prilaku dan sebagainya sewaktu kejadian tersebut belaku atau sewaktu prilaku tersebut terjadi. Dengan cara pengamatan data yang langsung mengenai perilaku dari suatu objek dapat segera dicatat dan tidak menggantungkan dari ingatan seseorang.

2. Dapat diperoleh data dari subjek yang bersangkutan secara langsung.

Selain keuntungan yang diperoleh dari pengamatan langsung juga terdapat kelemahannya :
1. Diperlukan waktu menunggu yang lama untuk dapat melakukan pengamatan langsung dari suau kejadian

2. Pengamatan terhadap suatu penomena yang lama tidak dapat dilakukan secara langsung

Pada tahap observasi terdapat beberapa data yang diperoleh :

Data primer

$\diamond$ Melihat dan mengamati langsung lokasi perencanaan

$\diamond$ Mengetahui dan menentukan penggunaan ruang wilayah perencanaan

$\diamond \quad$ Mengetahui sumber air bersih

$\diamond \quad$ Mengetahui perkiraan kebutuhan air bersih

$\diamond$ Mengetahui jumlah populasi yang menggunakan air bersih

$\diamond$ Mengetahui pengelolaan sampah.

Data sekunder

$\diamond$ Data sekunder pada perencanaan ini diperoleh dari Detail Engineering Desain Tempat Pelelangan ikan Karangsong Kabupaten Indramayu.

$\diamond$ Buku -buku laporan penelitian dan perencanaan terdahulu.

$\diamond$ Wawancara dengan petugas TPI Karangsong

$\diamond$ Wawancara dengan pegawai Dinas Perikanan dan Kelautan Kabupaten Indramayu

\section{Teknis Analisis Data}

Analisis data adalah bagian dari pengolahan data yang diawali dengan melakukan penilaian terhadap kondisi sistem sanitasi yang ada, dilanjutkan dengan mengidentifikasi permasalahan dan mengusulkan alternatif pemecahannya dengan memperhatikan kendalakendala yang ada. Pada tahap ini juga 
dikembangkan teknologi sanitasi pengolahan, bahan serta konstruksinya, setelah didapat alternatif terpilih kemudian menyusun perencanaan sarana sanitasi. Dalam perencanaan sistem sanitasi Tempat Pelelangan Ikan Higienis ini dilakukan beberapa metode antara lain :

1. Mengidentifikasi kondisi existing sistem sanitasi

2. Menghitung kebutuhan air bersih

3. Menghitung timbulan air limbah

\section{Hasil dan Pembahasan}

\section{Identifikasi Kondisi Existing}

Tempat Pelelangan Ikan Karangsong di Kabupaten Indramayu memiliki luas kurang lebih $4000 \mathrm{~m}^{2}$ terdiri dari bangunan-bangunan sebegai berikut :

- Gedung TPI

- Kantor pengelola

- Kantor Koperasi Perikanan Laut

- Toko suku cadang perahu motor

- Depot dan penggilingan es

- Balai pertemuan

- WC umum

- Rumah pompa

- Pos security

- Mushola

Fasilitas sanitasi yang ada antara lain :

- Penyediaan air bersih

- Penyaluran air buangan dan drainase

- Pengelolaan dan pengolahan sampah

Ada terdapat 1 sungai dan 1 kanal yang saling berhubungan dapat digunakan untuk mengalirkan air buangan dari Tempat pelelangan Ikan yang selanjutnya mengalir ke laut. Selain untuk mengalirkan air limbah air sungai ini juga digunakan sebagai sumber air baku untuk memenuhi kebutuhan air bersih di Tempat Pelelangan Ikan.
Tabel 1. Rekapitulasi Keb. Air Bersih TPI

\begin{tabular}{clc}
\multicolumn{3}{c}{ Karangsong } \\
\hline No & \multicolumn{1}{c}{ Fasilitas } & $\begin{array}{c}\text { Keb. Air } \\
\text { Bersih } \\
\text { (l/unit/hari) }\end{array}$ \\
\hline 1 & Gedung TPI & 2165 liter/hari. \\
\hline 2 & Kantor Pengelola & 1100 1/unit/hari \\
\hline 3 & $\begin{array}{l}\text { Kantor Koperasi } \\
\text { Perikanan Laut }\end{array}$ & 1100 1/unit/hari \\
\hline 4 & $\begin{array}{l}\text { Toko suku cadang } \\
\text { perahu motor }\end{array}$ & 500 l/unit/hari \\
\hline 5 & Masjid & 800 l/unit/hari \\
\hline 6 & WC umum & 150 l/org/hari \\
\hline 7 & Balai Pertemuan & 1000 1/org/hari \\
\hline
\end{tabular}

Dengan mengetahui besarnya kebutuhan air bersih, kemudian melakukan identifikasi terhadap kebutuhan air bersih di TPI Karangsong, Kabupaten Indramayu. Dalam perhitungan kebutuhan air bersih ini, diasumsikan tidak ada penambahan unit/ orang tiap tahunnya.

\section{Kebutuhan Air Bersih Gedung TPI}

Diketahui luas TPI adalah $4000 \mathrm{~m}^{2}$ data produksi ikan selama tahun 2008 - 2010 menunjukan jumlah tertinggi terjadi pada bulan november tahun 2010 yaitu $194853 \mathrm{~kg}$.Untuk mencuci ikan seberat $30 \mathrm{~kg}$ membutuhkan air bersih sebanyak 10 liter, perbandingan 3:1, maka untuk membersihkan $194853 \mathrm{~kg}$ ikan membutuhkan air 64951 liter

$$
\begin{aligned}
\frac{194853}{3} & =64951 \\
& =64951 \frac{l}{\text { bln }} \times \frac{1 \text { bln }}{30 \text { hari }} \times \frac{1 \text { hari }}{86400 \text { det }} \\
& =0,025 \frac{\text { liter }}{\text { detik }}
\end{aligned}
$$

\section{Fluktuasi Air}

Pemakaian jam puncak yaitu pemakaian terbanyak perjam dalam satu hari. Pengaliran puncak ini terjadi akibat adanya penggunaan air secara bersamaan. Pemakaian jam puncak dapat diketahui dengan menggunakan persamaan :

Kebutuhan jam puncak $=f m h \times$ Qtotal $=$ $1,75 \times 0.025 \mathrm{l} /$ detik 


$$
=0,04375 \frac{l}{d e t} .
$$

Kebutuhan air bersih untuk kantor pengelola TPI

$$
\begin{gathered}
=\frac{\text { std. Keb. Air bersih } \times \text { jml unit }}{86400 \text { det } / \text { hari }} \\
=\frac{1100 \frac{\text { liter }}{\text { unit } / \text { hari }} \times 1 \text { unit }}{86400 \text { detik } / \text { hari }} \\
=0,013 \text { liter } / \text { det }
\end{gathered}
$$

Kebutuhan air bersih untuk kantor koperasi

$$
\begin{gathered}
=\frac{\text { std. Keb. Air bersih } \times j m l \text { unit }}{86400 \text { det } / \text { hari }} \\
=\frac{1100 \frac{\text { liter }}{\text { unit } / \text { hari }} \times 1 \text { unit }}{\begin{array}{c}
86400 \text { detik } / \text { hari } \\
=0,013 \text { liter } / \text { det }
\end{array}}
\end{gathered}
$$

Kebutuhan air bersih untuk pertokoan

$$
\begin{aligned}
= & \frac{\text { std. } \text { Keb. Air bersih } \times \text { jml unit }}{86400 \mathrm{det} / \text { hari }} \\
= & \frac{500 \frac{\text { liter }}{\text { unit } / \text { hari }} \times 8 \text { unit }}{86400 \text { detik } / \text { hari }} \\
= & 0,05 \text { liter } / \text { det }
\end{aligned}
$$

Kebutuhan air bersih untuk balai pertemuan

$$
\begin{aligned}
& =\frac{\text { std. } \text { Keb. } \text { Air bersih } \times j m l \text { unit }}{86400 \text { det } / \text { hari }} \\
& =\frac{1000 \frac{\text { liter }}{\text { unit } / \text { hari }} \times 1 \text { unit }}{86400 \text { detik } / \text { hari }}
\end{aligned}
$$

$$
=0,012 \frac{\text { liter }}{\text { det }}
$$

Kebutuhan air bersih untuk masjid

$$
\begin{aligned}
& =\frac{\text { std. Keb. Air bersih } \times \text { jml unit }}{86400 \text { det } / \text { hari }} \\
& =\frac{800 \frac{\text { liter }}{\text { unit } / \text { hari }} \times 1 \text { unit }}{86400 \text { detik } / \text { hari }} \\
& =0,00925 \text { liter } / \text { det }
\end{aligned}
$$

Kebutuhan air bersih untuk toilet umum

Asumsi orang berkumpul terbanyak di TPI berjumlah 1000 orang

$$
\begin{aligned}
&= \frac{\text { std. Keb. Air bersih } \times j m l \text { unit }}{86400 \text { det } / \text { hari }} \\
&= \frac{150 \frac{\text { liter }}{\text { orang } / \text { hari }} \times 1000 \text { orang }}{86400 \text { detik } / \text { hari }} \\
&=1,74 \text { liter } / \text { det }
\end{aligned}
$$

Akumulasi kebutuhan air bersih $=\frac{(0.025+0.013+0.013+0.05+0.012+0.009+1.74) \text { liter }}{\text { detik }}=$ $1.862 \frac{\text { liter }}{\text { detik }}$

Kebutuhan air bersih di TPI Karangsong untuk lebih jelasnya dapat dilihat pada tabel berikut ini.

Tabel 2. Kebutuhan Air bersih TPI Karangsong di Kabupaten Indramayu

\begin{tabular}{llllc}
\hline No & \multicolumn{1}{c}{ Jenis Fasilitas } & Keb. Air Bersih & \multicolumn{1}{c}{$\begin{array}{c}\text { Jumlah } \\
\text { Fasilitas/Orang }\end{array}$} & $\begin{array}{c}\text { Total Keb. Air } \\
\text { Bersih L/detik }\end{array}$ \\
\hline 1 & Gedung TPI & 2165 liter/hari & 64951Ikan & 0,025 \\
\hline 2 & Kantor Pengelola TPI & 1100 L/unit/hari & 1 Unit & 0,013 \\
\hline 3 & Kantor Koperasi PL & 1100 L/unit/hari & 1 Unit & 0,013 \\
\hline 4 & Pertokoan & 500 L/unit/hari & 8 Unit & 0,05 \\
\hline 5 & Masjid & 800 L/unit/hari & 1 Unit & 0,009 \\
\hline 6 & WC umum & 150 L/org/hari & 1000 Orang & 1,74 \\
\hline 7. & Balai Pertemuan & 1000 L/unit/hari & 1 Unit & 0,012 \\
\hline $\begin{array}{l}\text { Akumulasi Keb. Air Bersih } \\
\text { (L/unit/detik) }\end{array}$ & & & $\mathbf{1 , 8 6 2}$ \\
\hline
\end{tabular}




\section{Fluktuasi Air}

Pemakaian jam puncak yaitu pemakaian terbanyak perjam dalam satu hari. Pengaliran puncak ini terjadi akibat adanya penggunaan air secara bersamaan. Pemakaian jam puncak dapat diketahui dengan menggunakan persamaan :

Kebutuhan jam puncak $=f m h \times$ Qtotal

$$
\begin{gathered}
=1,75 \times 1,837 \mathrm{l} / \text { detik } \\
=3,21 \frac{l}{d e t} .
\end{gathered}
$$

Tabel 3. Rekapitulasi kebutuhan air bersih dan timbulan air buangan

\begin{tabular}{llccc}
\hline No & JenisFasilitas & $\begin{array}{c}\text { Keb. Air Bersih } \\
\text { (L/detik) }\end{array}$ & \% a.b & $\begin{array}{c}\text { Jumlah Air } \\
\text { Buangan(l/detik) }\end{array}$ \\
\hline 1 & Gedung TPI & 0,025 & 100 & 0,025 \\
\hline 2 & Kantor Pengelola TPI & 0,013 & 80 & 0,010 \\
\hline 3 & Kantor Koperasi PL & 0,013 & 80 & 0,010 \\
\hline 4 & Pertokoan & 0,05 & 80 & 0,04 \\
\hline 5 & Masjid & 0,009 & 80 & 0,0072 \\
\hline 6 & Balai Pertemuan & 0,012 & 80 & 0,0096 \\
\hline 7 & WC umum & 1,74 & 80 & 1,392 \\
\hline & Jumlah & $\mathbf{1 , 8 6 2}$ & & $\mathbf{1 , 4 9 4}$ \\
\hline
\end{tabular}

\section{Identifikasi Karakteristik Air Buangan}

Identifikasi karaktersitik air buangan berguna untuk mengetahui jenis pengolahan mana yang terbaik dalam menanggulangi air buangan

\section{Identifikasi Air Buangan}

Setelah mengetahui besarnya kebutuhan air bersih dari hasil identifikasi, kemudian mengidentifikasi timbulan air buangannya yang dianggap $80 \%$ dari besarnya kebutuhan air bersih (Pratiwi \& Purwanti, 2015), kecuali pada gedung TPI karena air bersih digunakan untuk mencuci ikan (air langsung terbuang). Untuk lebih jelasnya dapat dilihat ada Tabel 3.

Tabel 4. Hasil Uji Air Limbah Pencucian Ikan

\begin{tabular}{llcc}
\hline No. & \multicolumn{1}{c}{ Parameter } & Satuan & Hasil Laboratorium \\
\hline A. & Fisika & & \\
1. & Salinitas & $\% 0$ & 11,1 \\
2. & Temperatur & ${ }^{\circ} \mathrm{C}$ & 29,1 \\
3. & Zat Padat Tersuspensi (TSS) & $\mathrm{mg} / \mathrm{l}$ & $>825$ \\
\hline B. & Kimia & & \\
1. & Amoniak Bebas $\left(\mathrm{NH}_{3}-\mathrm{N}\right)$ & $\mathrm{mg} / \mathrm{l}$ & $>137,50$ \\
2. & BOD & $\mathrm{mg} / \mathrm{l}$ & 836 \\
3. & $\mathrm{COD}$ & $\mathrm{mg} / \mathrm{l}$ & 1286 \\
4. & Fenol & $\mathrm{mg} / \mathrm{l}$ & 1,900 \\
5. & Nitrat $\left(\mathrm{NO}_{3}-\mathrm{N}\right)$ & $\mathrm{mg} / \mathrm{l}$ & 150 \\
6. & $\mathrm{Nitrit}\left(\mathrm{NO}_{2}-\mathrm{N}\right)$ & $\mathrm{mg} / \mathrm{l}$ & 0,154 \\
7. & $\mathrm{pH}$ & - & 6,83 \\
\hline
\end{tabular}


Hasil uji kualitas air limbah TPI Karangsong memperlihatkan bahwa terdapat beberapa parameter yang tinggi, yaitu amoniak bebas, BOD (Biochemical Oxygen Demand), COD (Chemical Oxygen Demand) serta nitrat. Tingginya konsentrasi beberapa parameter tersebut menandai kebutuhan instalasi pengolahan air limbah sebelum dibuang ke badan air penerima.

Alternatif instalasi pengolahan air limbah dapat berupa unit septic tank termodifikasi, yaitu bangunan septic tank yang memiliki beberapa kompartemen dengan media biofilter (Wisesa \& Slamet, 2016). Pada unit ini, diperkirakan proses pengolahan dapat berjalan lebih baik sehingga dapat menyisihkan zat organik dengan efisiensi yang lebih tinggi dibandingkan dengan septic tank biasa.

Limbah padat yang ditimbulkan berupa sampah potongan ikan atau bagian-bagian ikan dapat ditempatkan dalam wadah sampah organik dan diolah menjadi pupuk. Jika limbah ikan tersebut belum tercampur dengan sampah padat lainnya, maka potensi pemanfaatan kembali menjadi tepung ikan dapat dilakukan (Sedianingsih, Mooniarsih, \& Sujana, Maret 2014).

Seluruh kegiatan yang terkait dengan sanitasi harus disertai dengan kesadaran masyarakat di sekitarnya (Ningrum, 2017). Kesadaran ini diimplementasikan dalam bentuk perilaku yang menunjang berjalannya aturan dan prosedur pelaksanaan program-program sanitasi di TPI.

\section{Kesimpulan}

Berdasarkan penelitian ini dapat diperoleh beberapa hal penting yaitu:

- Kebutuhan air bersih gedung TPI adalah $0,025 \mathrm{l} / \mathrm{d}$, dengan fluktuasi air sebesar $0,04375 \mathrm{l} / \mathrm{d}$.

- Kebutuhan air bersih untuk kantor pengelola TPI adalah 0,031 1/d; untuk kantor koperasi adalah 0,031, unuk pertokoan sebesar 0,05 1/d.

- Kebutuhan air untuk balai perteman adalah sebesar 0,012 1/d, untuk mesjid sebesar $0,00925 \mathrm{l} / \mathrm{d}$, untuk toilet umum adalah $1,8621 / d$

- Secara total kebutuhan air bersih untuk kegiatan TPI dan aktivitas pendukungnya adalah sebesar 1,862 1/d dengan kebutuhan jam puncak sebesar $3,211 / d$.

- Jumlah total air buangan adalah 1,494 $1 / \mathrm{d}$

- Hasil uji kualitas air limbah TPI Karangsong memperlihatkan bahwa terdapat beberapa parameter yang tinggi, yaitu amoniak bebas, BOD, COD, serta nitrat. Tingginya konsentrasi beberapa parameter tersebut menandai kebutuhan instalasi pengolahan air limbah sebelum dibuang ke badan air penerima.

- Alternatif instalasi pengolahan air limbah dapat berupa unit septic tank termodifikasi, yaitu bangunan septic tank yang memiliki beberapa kompartemen.

\section{Daftar Pustaka}

Ningrum, P. T. (2017). Kondisi Sanitasi Tempat Pelelangan Ikan dan Pengelolaan Limbah di Wilayah Pesisir Puger Kabupaten Jember. Prosiding Seminar Nasional Kelautan dan Perikanan III , 321-326.

Pratiwi, R. S., \& Purwanti, I. F. (2015). Perencanaan Sistem PenyaluranAir Limbah Domestik di Kelurahan Keputih Surabaya. JURNAL TEKNIK ITS , Vol. 4, No. 1: D-40-D44.

Sedianingsih, P., Mooniarsih, N. T., \& Sujana, I. (Maret 2014). Rancang Bangun Mesin Pengolah Limbah Ikan Menjadi Tepung Ikan. Jurnal ELKHA, Vol.6 No 1: 37-40. 
Wisesa, D. M., \& Slamet, A. (2016). Perencanaan Instalasi Pengolahan Air Limbah (IPAL) di Rumah Susun Tanah
Merah Surabaya. JURNAL TEKNIK ITS , Vol. 5, No. 2: D199-D203. 